\title{
Physicochemical quality maintenance and bioactive compounds enhancement of Thai guava fruit cv. 'Kim Ju' by using combinative hot water and methyl jasmonate immersion
}

\author{
Suriyan Supapvanich ${ }^{*}$, Yuranan Kernprie ${ }^{1}$, Panida Boonyaritthongchai ${ }^{2}$, Chairat Techavuthiporn ${ }^{3}$, \\ Racha Tepsorn ${ }^{4}$ and Pannipa Youryon ${ }^{5}$
}

${ }^{1}$ Department of Agricultural Education, Faculty of Industrial Education and Technology, King Mongkut's Institute of Technology Ladkrabang, Ladkrabang, Bangkok, Thailand, ${ }^{2}$ Postharvest Technology Program, School of Bioresources and Technology, King Mongkut's University of Technology Thonburi, Bangkok, Thailand, ${ }^{3}$ Division of Biological Science, Faculty of Science and Technology, Huachiew Chalermprakiet University, Samutprakarn, Thailand, ${ }^{4}$ Department of Food Science and Technology, Faculty of Science and Technology, Thammasat University, Prathumthani, Thailand, ${ }^{5}$ Department of Agricultural Technology, Prince of Chomphon campus, King Mongkut's Institute of Technology Ladkrabang, Chomphon, Thailand

\section{A B S T R A C T}

\begin{abstract}
Postharvest life of Thai guava fruits is limited due to skin damage and physicochemical changes during cold storage. Both methyl jasmonate (MeJA) and heat treatments are potential approaches maintaining postharvest quality of fruits. Thus, the aim of this work was to investigate the effects of hot water and MeJA immersion on physicochemical quality of 'Kim Ju' guava fruit during storage at $12 \pm$ $1{ }^{\circ} \mathrm{C}$ for $18 \mathrm{~d}$. The fruit were immersed in hot water at $40{ }^{\circ} \mathrm{C}$ for $30 \mathrm{~min}(\mathrm{H}), 0.1 \mathrm{mM}$ MeJA for $10 \mathrm{~min}(0.1 \mathrm{mM} \mathrm{MeJA})$ or $\mathrm{H}$ followed by $0.1 \mathrm{mM} \mathrm{MeJA}(\mathrm{H}+0.1 \mathrm{mM}$ MeJA) and untreated fruit were used as control. The determined parameters were visual appearance, colour, texture, pectin substances, antioxidant activities, bioactive compounds and antioxidant enzymes activities. The results showed that $\mathrm{H}+0.1 \mathrm{mM}$ MeJA treatment maintained visual appearance and colour as compared to $0.1 \mathrm{mM}$ MeJA, $\mathrm{H}$ or control treatment, consequently. The treatment of $\mathrm{H}+0.1 \mathrm{mM}$ MeJA retarded softening according to the inhibition of soluble pectin increase and insoluble pectin decrease. The treatment enhanced the both antioxidant and free radical scavenging activities as compared to control. These were accompanied with the increments of bioactive compounds such as ascorbic acid, total phenols, flavonoids and peroxidase activity and the retardation of catalase activity decrease. In conclusion, the $\mathrm{H}+0.1 \mathrm{mM}$ MeJA treatment could maintain postharvest qualities involving visual appearance and texture and enhanced nutritional value of guava fruit during cold storage.
\end{abstract}

Keywords: Guava fruit; Heat treatment; Methyl jasmonate; Softening; Bioactive compounds

\section{INTRODUCTION}

Guava (Psidium guajava L.) is a well-known exotic tropical fruit containing high nutritional values, especially antioxidants, vitamin $\mathrm{C}$, dietary fibre and minerals (Rai et al., 2010). Guava is an important commercial fruit in Thailand where is one of guava producers to global market (FAO, 2011). Most commercial guava cultivars grown in Thailand are white guavas and consumed at mature-green stage. The bright-green peel colour, crispy white flesh and sweet with slight sour taste are the desirable eating characteristics of Thai guavas. The well-known commercial
Thai guava cultivars are 'Klom Salee', 'Paen Srithong' and 'Kim Ju'. Among these commercial cultivars, 'Kim Ju' guava has been the most acceptable cultivar for market and its demand is high. However, the main problems affecting the commercialization of Thai guavas are highly perishability due to moisture loss, skin browning incidence, softening and fungal deterioration. Under tropical condition in Thailand, guava fruit generally undergo rapid ripening in 3-4 days at room temperature which cold storage is required to preserve postharvest quality. However, cold storage alone may not enough to control the postharvest problems of the fruit and it may induce

\footnotetext{
${ }^{*}$ Corresponding author:

Suriyan Supapvanich, Department of Agricultural Education, Faculty of Industrial Education and Technology, King Mongkut's Institute of Technology Ladkrabang, Ladkrabang, Bangkok, Thailand. E-mail: suriyan.su@kmitl.ac.th
}

Received: 03 March 2019; Accepted: 01 May 2019 
chilling injury (González-Aguilar et al., 2004). Typical chilling injury symptoms found in guava during storage are skin discoloration and browning incidence (Goulart Nunes Mamede et al., 2016). The recommended optimum storage temperature of guava is about $10^{\circ} \mathrm{C}$ (Kader, 1999; Silip and Hajar, 2007). Kader (1999) suggested that mature guava can be held at $10{ }^{\circ} \mathrm{C}$ for $2-3$ weeks. Recently, several postharvest treatments have been applied with cold storage in order to maintain postharvest quality, prolong shelf-life and alleviate physiological disorders of fresh commodities (Wills et al., 2007). Heat treatments including hot water immersion, hot air and hot vapour have been utilised as quarantine treatment for guavas (Gould, 1994; McGuire, 1997; Wang and Lin, 2009). Heat treatment is feasible to retard ripening, prevent decay and delay the reduction of bioactive compounds in a number of flesh commodities during storage (Jin, et al., 2009; Promyou et al., 2012; Supapvanich et al., 2012). McGuire (1997) suggested that hot water immersion at $46.1^{\circ} \mathrm{C}$ for 35 minutes minimized overall loss of guava quality during storage. Recently the combination of heat treatment with other postharvest approaches including controlled atmosphere storage (Murray et al., 2007) or chemical treatments (Cao et al., 2010; Supapvanich and Promyou, 2017) have been applied for postharvest quality maintenance beside cold storage alone.

Methyl jasmonate (MeJA) is recognised as an elicitor playing important roles in responses to stresses and plant development (Zhao et al., 2013; Asghari and Hasanlooe 2016; Somata et al., 2017). Postharvest application of MeJA can alleviate physiological disorders, especially chilling injury, control postharvest diseases and enhance nutritional value such as antioxidant and bioactive compounds in fruit and vegetables (Wolucka et al., 2005; Khan and Singh, 2007; Men et al., 2009; Wang et al., 2015; Pereira da Silva et al., 2017). Asgjari and Hasanlooe suggested that exogenous MeJA application enhanced postharvest life, total antioxidant activity and antioxidant enzymes yields of 'Sabrosa' strawberry fruit during storage. González-Aguilar et al. (2004) reported that MeJA treatment alleviated skin browning and discoloration caused by chilling injury, induced sugars accumulation and enhanced ascorbic acid content in both white and red guavas. These indicate that MeJA treatment is a potential means for maintaining physicochemical quality and alleviating physiological disorders and enhancing antioxidant activity of fresh commodities during storage. However, the combinative use of heat and MeJA treatment on postharvest quality of guavas is not found at moment. Thus, the aim of this work was to investigate the combinative effects of hot water and MeJA treatment on physicochemical quality of 'Kim Ju' guava fruit during cold storage.

\section{MATERIALS AND METHODS}

\section{Plant materials and MeJA solutions preparation}

'Kim Ju' Guava (Psidium guajava L.) fruit were purchased from an orchard at Baan-Na district, Nakon Nayok province, Thailand. The fruit were harvested at commercial mature-green stage (100 d after anthesis). The fruit quality were screened on the basis of uniform size (200-230 $\mathrm{g}$ per fruit) and free from physical damages and diseases at the orchard before delivered to Crop Production Technology Laboratory, Department of Agricultural Education, King Mongkut's Institute of Technology Ladkrabang within $2 \mathrm{~h}$. The fruit were again screened using Minolta colorimeter CR 300 (Minolta Camera Co., Japan) which the $a^{*}$ value of fruit peel was in the range of -15 to -17 . Afterwards, they were cleaned with tapped water and air-dried at room temperature (RT) $\left(28 \pm 1^{\circ} \mathrm{C}\right)$ for $15 \mathrm{~min}$.

\section{Treatments}

In our preliminary experiments, the effects of MeJA concentrations and hot water treatments on physical quality of 'Kim Ju' guava fruits were determined. We found that $0.1 \mathrm{mM}$ MeJA immersion for $10 \mathrm{~min}$ maintained overall visual appearance and retarded skin damage of the fruit rather than the immersion of $0.01 \mathrm{mM}$ MeJA and control treatment. Hot water immersion at $45^{\circ} \mathrm{C}$ for 15 or $30 \mathrm{~min}$ caused the peel browning incidence while the fruit were immersed in hot water at $40{ }^{\circ} \mathrm{C}$ for 30 min maintained overall visual appearance better than the fruit immersed in hot water at $40^{\circ} \mathrm{C}$ for $15 \mathrm{~min}$ and control, respectively (data not shown). In this experiment, the fruit were divided into 4 groups, using 35 fruit per group; in the first group, the fruit were immersed in water at RT for $30 \mathrm{~min}$ (control), in the second group, the fruit were immersed in hot water at 40 ${ }^{\circ} \mathrm{C}$ for $30 \mathrm{~min}(\mathrm{H})$, in the third group, they were immersed in $0.1 \mathrm{mM} \mathrm{MeJA}$ solution for $10 \mathrm{~min}(0.1 \mathrm{mM} \mathrm{MeJA})$ and in the fourth group, they were immersed in $\mathrm{H}$ followed by immersion in $0.1 \mathrm{mM}$ MeJA $(\mathrm{H}+0.1 \mathrm{mM} \mathrm{MeJA})$. After treatments, the fruit were air-dried at RT for $15 \mathrm{~min}$. The fruit was individually wrapped with a LLDPE film (commercial plastic film for guava) and covered with a foam net before storage at $12 \pm 1{ }^{\circ} \mathrm{C}, 87 \pm 2 \% \mathrm{RH}$ for $18 \mathrm{~d}$. Five fruit of each treatment were separated to investigate visual appearance, weight loss and superficial colour attributes throughout storage. Other five fruits were periodically taken to determine texture, pectin substances, ferric reducing antioxidant potential (FRAP), free radical scavenging activity, bioactive compounds such as ascorbic acid (AsA), total phenols and flavonoids contents and certain antioxidant enzymes activities such as catalase (CAT) and peroxidase (POD) in every $3 \mathrm{~d}$ during storage.

Visual appearance and colour attributes measurements Visual appearance of the fruit during storage was estimated by taking photographs. Guavas were periodically taken 
photographs on day $0,6,12$ and 18 of the storage. Superficial colour attributes of the fruit were measured using a Minolta colorimeter CR-300 (Minolta Camera Co., Japan). Colour attributes such as $L^{*},-a^{*}, b^{*}$, and $\Delta E^{*}$ values of the fruit skin were recorded.

\section{Texture measurement}

Texture of the guavas was measured using a TA Plus Texture Analyzer (Lloyds, England) with a blade probe for cutting force measurement. The fruit were prepared by vertically cutting into 8 pieces and the endocarp was removed. The blade was driven at a speed of $20 \mathrm{~mm} \mathrm{sec}^{-1}$ to a depth of $5 \mathrm{~mm}$ at the middle part of guava wedge. The maximum cutting force (Newton, $\mathrm{N}$ ) was recorded.

Soluble- and insoluble-pectin substances determination Fifteen gram of guava flesh was homogenized with $80 \%$ $(\mathrm{v} / \mathrm{v})$ acetone at room temperature and the homogenate was filtered through a GF/A filter paper. All cell wall hydrolases in the cake were inactivated by adding phenol: acetic acid: water $(2: 1: 1, \mathrm{v} / \mathrm{v} / \mathrm{v})$ was added into the cake and left at RT for $1 \mathrm{~h}$. The sample was filtered through a GF/A filter paper and rinsed with $80 \%$ acetone three times followed by $100 \%$ acetone one time. The sample was dried in a desiccator. A $0.5 \mathrm{~g}$ of the acetone insoluble solid (AIS) was extracted with $50 \mathrm{mM}$ Ethylenediaminetetraacetic acid (EDTA) consisting of $50 \mathrm{mM}$ sodium acetate, $\mathrm{pH} 7$, solution for $6 \mathrm{~h}$ at RT and then filtered using GF/A filter paper. The filtrate was collected and the cake was again extracted with $20 \mathrm{~mL}$ of $50 \mathrm{mM}$ sodium carbonate $\left(\mathrm{Na}_{2} \mathrm{CO}_{3}\right)$ consisting of $20 \mathrm{mM}$ sodium borohydride $\left(\mathrm{NaBH}_{4}\right)$ solution for $12 \mathrm{~h}$ at $4{ }^{\circ} \mathrm{C}$ followed by at RT for $2 \mathrm{~h}$ and then filtrated. Absolute ethanol was added into the both filtrates by making up the alcohol concentration to $80^{\circ}(\mathrm{v} / \mathrm{v})$ and the mixtures were left at RT for $24 \mathrm{~h}$ before filtrated. The precipitates of both EDTA and $\mathrm{Na}_{2} \mathrm{CO}_{3}$ extractions were used to determine the concentration of soluble- and insoluble pectins, consequently, using method of Ahmed and Labavitch (1978). The concentration of both pectin substances was expressed as g galacturonic acid (GalA) per kg AIS $\left(\mathrm{g} \mathrm{kg}^{-1}\right)$.

\section{Antioxidant capacity and free radical scavenging activity assays}

Five grams of guava flesh was homogenized with $15 \mathrm{~mL}$ of $80^{\circ}(\mathrm{v} / \mathrm{v})$ ethanol. Total volume of homogenate was adjusted to $30 \mathrm{~mL}$ with distilled water. The sample was stirred at RT for $30 \mathrm{~min}$ and then filtered through Whatman No.1 filter paper. The filtrate was collected to determine antioxidant capacity, free radical scavenging, total phenols and flavonoids contents. Antioxidant capacity of the extract was determined using Ferric reducing antioxidant potential (FRAP) method which described by Benzie and Strain (1996) with slight modification. A $0.1 \mathrm{~mL}$ of the extract was reacted with $2.9 \mathrm{~mL}$ FRAP reagent, consisting of acetate buffer $\mathrm{pH} 3$, $10 \mathrm{mM}$ 2,4,6-tripyridyl-1,3,5-triazine (TPTZ) and $20 \mathrm{mM}$ ferric chloride hexahydrate in the ratio of 10:1:1. The reaction was left at $\mathrm{RT}$ for at least $30 \mathrm{~min}$. Absorbance at $630 \mathrm{~nm}$ was measured. Total antioxidant capacity was calculated using a standard curve of trolox. Data were as mole Trolox equivalents per $\mathrm{kg}$ fresh weight $\left(\mathrm{mol} \mathrm{kg}{ }^{-1}\right)$. DPPH free radical scavenging activity of the extract was slightly modified from the method of Brand-Williams et al. (1995). Three $\mathrm{mL}$ of the extract was reacted with $0.5 \mathrm{~mL}$ of $1 \mathrm{mM}$ DPPH in methanol. Absorbance at $517 \mathrm{~nm}$ was immediately measured after $1 \mathrm{mM}$ DPPH was added $\left(\mathrm{A}_{0}\right)$ and the reaction was left in dark place at RT for $3 \mathrm{~min}$ $\left(A_{3}\right)$. The absorbance was again recorded. The ability to scavenge DPPH free radical was calculated by using the following equation.

Free radical scavenging activity $(\%)=\left[\left(\mathrm{A}_{0}-\mathrm{A}_{3}\right) / \mathrm{A}_{0}\right] \times 100$

\section{Total phenols and flavonoids assays}

Total phenols and flavonoids concentration of the extract were determined using the method of Slinkard and Singleton (1977) and Jia et al. (1999), consequently. Total phenol assay was started when $1.0 \mathrm{~mL}$ of the extract was reacted with $1.0 \mathrm{~mL}$ of $50 \%$ (v/v) Folin-Ciocalteu reagent and $2 \mathrm{~mL}$ of saturated $\mathrm{Na}_{2} \mathrm{CO}_{3}$ solution. The reaction was left at $\mathrm{RT}$ for at least $30 \mathrm{~min}$. Absorbance at $750 \mathrm{~nm}$ was observed. Total phenols concentration was presented in term of $\mathrm{g}$ gallic acid per $\mathrm{kg}$ fresh weight $\left(\mathrm{g} \mathrm{kg}^{-1}\right)$. Flavonoids concentration assay was started when $1.0 \mathrm{~mL}$ of the extract was mixed with $3.0 \mathrm{~mL}$ of distilled water and $225 \mu \mathrm{L}$ of $0.5 \% \mathrm{NaNO}_{2}$. The reaction was left for 6 min at RT and then $450 \mu \mathrm{L}$ of $10 \% \mathrm{AlCl}_{3}-6 \mathrm{H}_{2} \mathrm{O}$ was added and left for $5 \mathrm{~min}$. Finally, $1.5 \mathrm{~mL}$ of $1.0 \mathrm{M} \mathrm{NaOH}$ was mixed. The absorbance at $510 \mathrm{~nm}$ was recorded and flavonoids concentration was expressed as g catechin equivalents per $\mathrm{kg}$ fresh weight $\left(\mathrm{g} \mathrm{kg}^{-1}\right)$.

\section{Ascorbic acid assay}

Five of guava flesh was extracted with $20 \mathrm{~mL}$ of cold $5 \%$ metaphosphoric acid using a homogenizer. The homogenate was centrifuged at $10,000 \mathrm{~g}$ for $15 \mathrm{~min}$ at $4{ }^{\circ} \mathrm{C}$. Ascorbic acid concentration was assayed using the method of Hashimoto and Yamafuji (2001). A $1.6 \mathrm{~mL}$ of the extract was well-mixed with $0.8 \mathrm{~mL}$ of $2 \%$ di-indophenol and then $1.6 \mathrm{~mL}$ of $2 \%$ thiourea and $0.4 \mathrm{~mL}$ of $1 \%$ dinitrophenol hydrazine were added. The reaction was left at $37^{\circ} \mathrm{C}$ for $3 \mathrm{~h}$ and $2 \mathrm{~mL}$ of $85 \%$ sulphuric acid was then added. The mixture was left at RT for at least $30 \mathrm{~min}$. Absorbance at $540 \mathrm{~nm}$ of the solution was observed and ascorbic acid concentration was calculated using a standard curve of ascorbic acid solution. Data were presented as $\mathrm{g}$ ascorbic acid per kg fresh weight $\left(\mathrm{g} \mathrm{kg}^{-1}\right)$. 


\section{CAT and G-POD activities assays}

Five gram of guava flesh was homogenised with $25 \mathrm{~mL}$ of $0.1 \mathrm{M}$ phosphate buffer ( $\mathrm{pH}$ 6.5) containing $0.3 \mathrm{~g}$ of polyvinylpolypyrrolidone (PVPP) at $4{ }^{\circ} \mathrm{C}$ and the homogenate was then stirred for $3 \mathrm{~h}$ at $4{ }^{\circ} \mathrm{C}$. Afterwards, it was filtered through a Whatman No. 1 filter paper. The extract was kept in an ice bath until used. CAT (EC 1.11.1.6) and Guaiacol-POD (G-POD) (EC 1.11.1.7) activities were determined using method of Andrade Cuvi et al. (2011) with slight modification. The reaction of CAT activity was started when $250 \mu \mathrm{L}$ of the extract was added into $1.0 \mathrm{~mL}$ of the mixture of $0.1 \mathrm{M}$ phosphate buffer $(\mathrm{pH} 7.0)$ and $0.15 \mathrm{mM}$ $\mathrm{H}_{2} \mathrm{O}_{2}$. Aliquots of $300 \mu \mathrm{L}$ of the reaction mixture were taken at $0,0.5,1.0,1.5,2.0,2.5$ and $3.0 \mathrm{~min}$. and then mixed with the solution of $300 \mu \mathrm{L}$ of $0.02 \mathrm{M} \mathrm{TiCl}_{4}, 200 \mu \mathrm{L}$ of conc. $\mathrm{H}_{2} \mathrm{SO}_{4}$ and $1.35 \mathrm{~mL}$ of distilled water to stop the enzyme reaction. Absorbance at $410 \mathrm{~nm}$ was recorded. Unit (U) of CAT activity was defined as the amount of consumed $\mathrm{H}_{2} \mathrm{O}_{2}$ per min per $\mathrm{g}$ fresh weight $\left(\mathrm{U} \mathrm{g}^{-1}\right)$. G-POD activity was started when $500 \mu \mathrm{L}$ of the extract was added into the solution of $600 \mu \mathrm{L}$ of $0.5 \%(\mathrm{v} / \mathrm{v})$ guaiacol mixed with $1.6 \mathrm{~mL}$ of phosphate buffer $(\mathrm{pH} 7.0)$. The absorbance at $470 \mathrm{~nm}$ was recorded when $300 \mu \mathrm{L}$ of $0.059 \mathrm{M} \mathrm{H}_{2} \mathrm{O}_{2}$ was added. Enzyme activity was determined by monitoring the increase in the absorbance at $470 \mathrm{~nm}$. The unit (U) of G-POD activity was defined in term of the increase in $\mathrm{OD}_{470}$ per min per $\mathrm{g}$ fresh weight $\left(\mathrm{U} \mathrm{g}^{-1}\right)$.

\section{Statistical analysis}

All data, except fruit appearance, were expressed as the mean of 10 fruits and standard deviation (SD). Statistical analysis was carried out using Analysis of variance (ANOVA) and the significance between means of data was compared using the least significant difference (LSD) test at the $5 \%$ level.

\section{RESULTS AND DISCUSSIONS}

\section{Peel colour attributes}

Fig. 1 shows superficial colour attributes such as $L^{*},-a^{*}$, $b^{*}$, and $\Delta E^{*}$ values, of the guavas during storage. Both $0.1 \mathrm{mM}$ MeJA and $\mathrm{H}+0.1 \mathrm{mM}$ MeJA immersions prevented the loss of peel $L^{*}$ value which they did not different over storage. Whereas, the $L^{*}$ value of control and $H$ treated guavas decreased during storage. The $-a^{*}$ value of all treatments remained constant throughout storage. A slight increase in $b^{*}$ value of all treatments was found but they did not show significant difference during storage. These indicated that $\mathrm{H}, 0.1 \mathrm{mM} \mathrm{MeJA}$ and $\mathrm{H}+0.1 \mathrm{mM}$ MejA treatments had no effect the changes in $-a^{*}$ and $b^{*}$ values of the guava fruit over the storage period. The $\Delta E^{*}$ value of the control and $H$ treated fruits was progressively increased throughout storage and higher than that of both $0.1 \mathrm{mM} \mathrm{MeJA}$ and $\mathrm{H}+0.1 \mathrm{mM}$ MeJA treated fruits, respectively. The increase in $\Delta E^{*}$ value was apparently related to the change in $L^{*}$ value during storage. This showed that the both MeJA treatments could retain

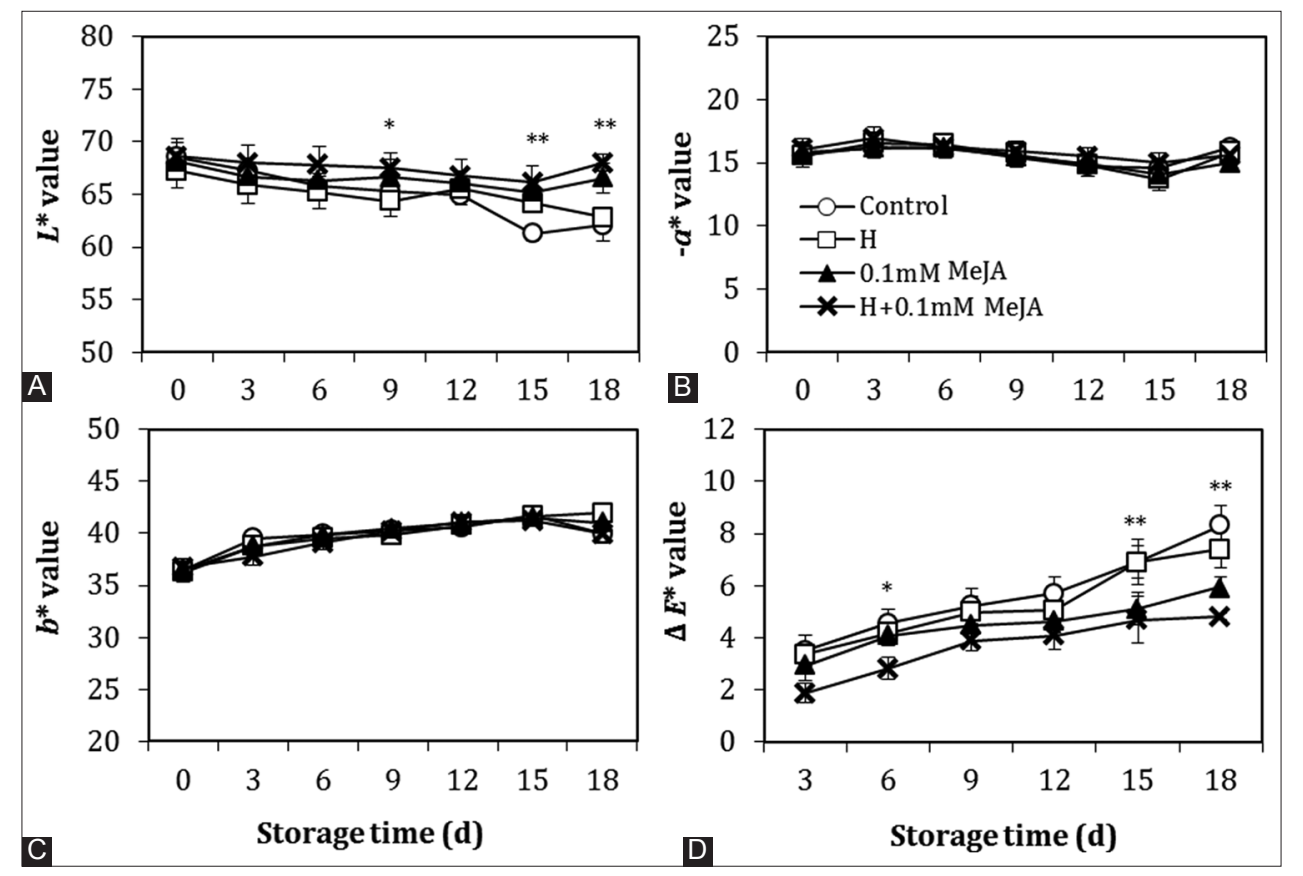

Fig 1. $L^{*}(\mathrm{~A}),-a^{*}(\mathrm{~B}), b^{\star}(\mathrm{C})$ and $\Delta E^{\star}(\mathrm{D})$ values of 'Kim Ju' guava immersed in water (control), hot water $(\mathrm{H}), 0.1 \mathrm{mM}$ methyl jasmonate (MeJA) or $\mathrm{H}+0.1 \mathrm{mM}$ MeJA during storage at $12 \pm 1^{\circ} \mathrm{C}$ for $18 \mathrm{~d}$. Vertical bars represent the standard deviation (SD) of mean $(n=5)$. Significant differences between untreated (control) and treated guava fruits are indicated with asterisk $\left[{ }^{* *}(p<0.01) ;{ }^{*}(p<0.05)\right]$. 
the peel brightness of guava fruit. This was in agreement with the work of Zhao et al. (2013) which reported that postharvest treatment of MeJA delayed the changes in $L^{*}$, hue angle and chroma values of 'Cavendish' bananas during storage. Boonyaritthongchai, et al. (2017) also suggested that postharvest immersion of MeJA lowered peel darkness of 'Nam Dok Mai' mango fruit during cold storage. As the results in Fig. $8 \mathrm{~A}$ and $1 \mathrm{D}$ showed that $\mathrm{H}$ treatment could not maintain $L^{*}$ and $\Delta E^{*}$ values of the fruit peel whilst $H$ + MeJA treatment retained those colour attributes of the fruit peel which was similar to MeJA treatment alone. This suggested that exogenous MeJA immersion at $0.1 \mathrm{mM}$ has more effect maintaining guava fruit colour than the hot water immersion.

\section{Visual appearance}

The visual appearance of guava fruits was shown in Fig. 2. It was shown that the visual appearance of guava fruit was accompanied with the superficial colour changes as shown in Fig. 1. Greenness of the fruits did not apparently change throughout the storage which was similar to the change in $-a^{*}$ value (Fig. 1B). Brown flecks on the fruit skin were slightly found in the control fruit after storage for $6 \mathrm{~d}$. On day 12, the visual appearance of control fruit looked worse than that of other treatments due to browning incidence and brown rots. The brown rot was found in control, $\mathrm{H}$ and $0.1 \mathrm{mM}$ MeJA treated fruits, whilst it was not found on $\mathrm{H}+0.1 \mathrm{mM} \mathrm{MeJA}$ treated fruit. This indicated that $\mathrm{H}+0.1 \mathrm{mM} \mathrm{MeJA}$ immersion could inhibit brown flecks and rots on guava fruit during cold storage for $18 \mathrm{~d}$. The increase in brown flecks or skin discolouration during storage was concomitant with the reduction of $L^{*}$ and the increase in $\Delta E^{*}$ values (Fig. 1A and 1D). González-Aguilar et al. (2004) suggested that skin browning and discolouration are typical symptoms of chilling injury or excessive water loss of guavas. Thus, the brown flecks found on guava skin in this recent work might be due to the symptom of chilling injury because the overall weight loss of guava fruit was lower than $3.5 \%$ over the storage (data not shown). The both MeJA treatments could retard peel browning incidence compared to control and $\mathrm{H}$ treated fruits. This was in agreement with the work of González-Aguilar et al. (2004) which MeJA application inhibited skin browning of both red- and white-flesh guavas during cold storage. The recent work also showed that $\mathrm{H}$ treatment alone could alleviate skin browning incidence but was not good enough as compared to MeJA immersions. McGuire (1997) reported that hot water quarantine treatment at $46.1 \pm 0.2^{\circ} \mathrm{C}$ for $35 \mathrm{~min}$ caused susceptibility to chilling injury and decay of guava. Similarly, our preliminary work showed that hot water immersion at $45 \pm 1{ }^{\circ} \mathrm{C}$ for 30 min caused skin damage within $24 \mathrm{~h}$ after treated (data not shown). This suggested that the proper hot water treatment of 'Kim Ju' guava fruit is approximately $40{ }^{\circ} \mathrm{C}$ for $30 \mathrm{~min}$, due to avoid skin damage caused by excessive heat. The combinative treatment of $\mathrm{H}$ and 0.1 $\mathrm{mM} \mathrm{MeJ}$ A could eliminate browning incidence and brown rots of the guava fruits better than the treatment of $\mathrm{H}$ or MeJA alone. This was in agreement with previous reports which the combination effect of heat and MeJA treatment alleviated skin damage caused by chilling injury and retained postharvest quality of peach fruit (Jin et al., 2009) and loquat fruit (Jin, et al., 2014). In the next determination, $\mathrm{H}+0.1 \mathrm{mM}$ MeJA immersion was selected to observe the physicochemical changes involving texture, pectin substances, bioactive compounds, certain antioxidant enzymes activities, antioxidant capacity and free radical scavenging activity of 'Kim Ju' guava fruit during storage.



Fig 2. Visual appearance of 'Kim Ju' guava fruits immersed in water (control), hot water $(\mathrm{H}), 0.1 \mathrm{mM}$ methyl jasmonate $(\mathrm{MeJA})$ or $\mathrm{H}+0.1 \mathrm{mM}$ MeJA during storage at $12 \pm 1^{\circ} \mathrm{C}$ for $18 \mathrm{~d}$. 


\section{Texture and pectin substances}

The changes in texture and the concentrations of both soluble (EDTA-soluble) and insoluble $\left(\mathrm{Na}_{2} \mathrm{CO}_{3}\right.$-soluble) pectins of control and $\mathrm{H}+0.1 \mathrm{mM} \mathrm{MeJA}$ treated guava fruits were presented in Fig. 3. Cutting force of the both control and treated fruit declined during the storage. Compared to the control, the cutting force of $\mathrm{H}+0.1 \mathrm{mM}$ MeJA treated guava fruits was higher over the storage period. At the end of the storage, the cutting force of control fruit declined approximately $37 \%$ whilst that of $\mathrm{H}+0.1 \mathrm{mM} \mathrm{MeJA}$ treated fruit decreased approximately $30 \%$ when compared to that of the fruit in initial day of storage. The reduction of cutting force of guava fruits was associated with the changes in both soluble and insoluble pectins concentrations during storage. On the initial of storage, amounts of the both soluble and insoluble pectins concentrations of each treatment were similar. Afterwards, soluble pectin concentration of both control and $\mathrm{H}+0.1 \mathrm{mM} \mathrm{MeJA}$ treated fruit was increased during storage. The soluble pectin content of control was significantly higher than that of $\mathrm{H}+0.1 \mathrm{mM}$ MeJA treated fruit throughout the storage $(P<0.05)$. Whilst, the insoluble pectin content of $\mathrm{H}+0.1 \mathrm{mM}$ MeJA treated fruit remained constant throughout the storage and was significantly higher than that of control fruit which continuously decreased throughout storage. It is commonly acknowledged that softening of fruit including guavas is concomitant with pectin modification and degradation leading to the increment of cell wall polymers solubilisation (El-Buluk et al., 1995; Supapvanich and Tucker, 2013). This work indicated that the treatment of $\mathrm{H}+0.1 \mathrm{mM}$ MejA retarded the softening of guava fruits by maintaining the high level of insoluble pectin content and inhibiting the increase in soluble pectin content during storage. Previous works suggested that both heat and MeJA treatments can disrupt the alteration of both cell wall components and membrane in fruit (Meng et al., 2010; Lara et al., 2006; Paull and Chen, 2000; Klein et al., 1990). Heat treatment alters cell wall composition by disrupting cell wall hydrolases (Paull and Chen, 2000), delaying pectin solubilisation and maintaining insoluble pectin content (Klein et al., 1990; Lara et al., 2006). Moreover, Heat treatment also strengthens cell membrane by maintaining the high level of unsaturated/ saturated fatty acids ratio and inhibiting membrane lipid peroxidation (Lurie, et al., 1995; Rui et al., 2010). MeJA treatment can reduce oxidative reaction of cell membrane (Cao, et al., 2009), inhibit pectin de-esterification and maintain high level of calcium content in cell wall (Meng et al., 2009). Thus, the combinative treatment of $\mathrm{H}$ and $0.1 \mathrm{mM}$ MeJA could retard the softening of guava fruit through the delay of cell wall modification and probably strengthening membrane structure.

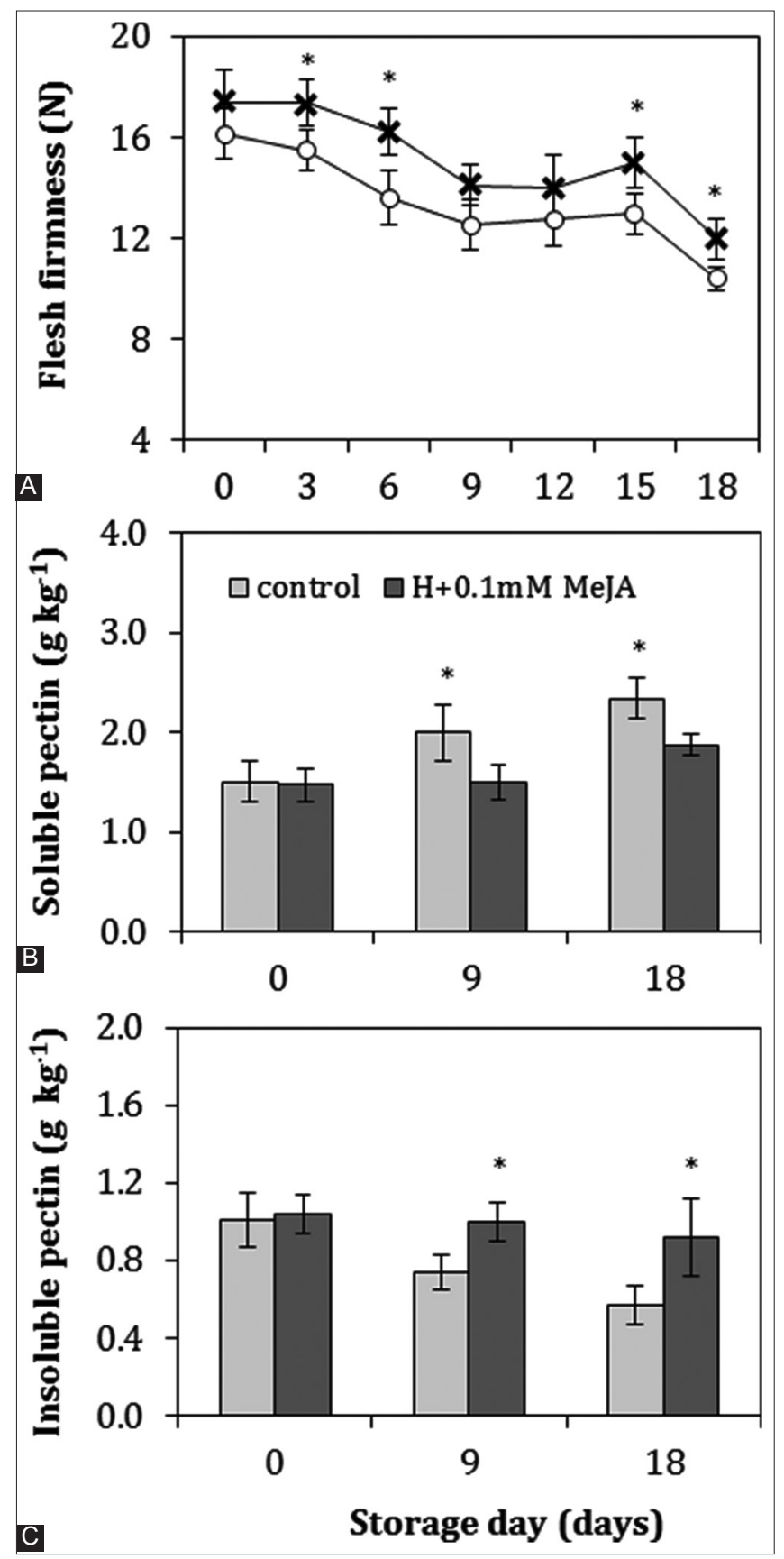

Fig 3. Flesh firmness (A), soluble pectin (B) and insoluble pectin (C) contents of 'Kim Ju' guava fruit immersed in water (control) or $\mathrm{H}+0.1$ $\mathrm{mM}$ MeJA during storage at $12 \pm 1{ }^{\circ} \mathrm{C}$ for $18 \mathrm{~d}$. Vertical bars represent the standard deviation (SD) of mean $(n=5)$. Significant differences between untreated (control) and treated 'Kim Ju' guava fruits are indicated with asterisk $\left[{ }^{* *}(p<0.01) ;{ }^{*}(p<0.05)\right]$.

\section{Ascorbic acid, total phenols and flavonoids concentrations}

Fig. 4 shows the changes in bioactive compounds including AsA, total phenols and flavonoids concentrations of guava fruits during storage. The results showed that AsA, total phenols and flavonoids concentrations were enhanced by $\mathrm{H}+0.1 \mathrm{mM}$ MeJA treatment. The AsA and total phenols contents of treated fruit increased 
during storage and reached to the peak on day 15 . Afterwards, both compounds declined apparently. Flavonoids content of $\mathrm{H}+0.1 \mathrm{mM}$ MeJA treated fruit also increased and reached to the peak on day 9 before gradually declined throughout storage. In control fruit, AsA concentration seemed constant throughout storage and total phenols concentration was retained for $15 \mathrm{~d}$ and then declined. The flavonoids concentration of control gradually increased during storage for $6 \mathrm{~d}$ and then declined throughout storage. The significant difference in flavonoids concentration of both control and $\mathrm{H}+0.1 \mathrm{mM}$ MeJA treated guava fruits was found after storage for $6 \mathrm{~d}$ which flavonoids content of the treated fruit was higher than that of control fruit until the end of storage. These results indicate that $\mathrm{H}+0.1 \mathrm{mM}$ MejA immersion can enhance bioactive compounds contents including total phenols, flavonoids and ascorbic acid of guava fruit. In a similar vein, Jin et al. (2009) reported that the combination of heat and MeJA treatment maintained the high levels of vitamin $\mathrm{C}$ and total phenols concentration of peach fruit over cold storage. Moreover, previous works also reported that both hot water and MeJA treatments could enhance bioactive compounds contents in fruit and vegetables (Kim et al., 2006; Mirdehghan et al., 2006; Schirra et al., 2007; Supapvanich, et al., 2012; Wang et al., 2015). It has been recently confirmed that MeJA induces phenylalanine ammonia-lyase activity leading to the accumulation of bioactive compounds and the enhancement of antioxidant system in plants (Wang and Zheng, 2005; Kim et al., 2006, Heredia and Cisneros-Zevallos, 2009; Wang, et al., 2015). Wolucka et al. (2005) suggested that MeJA treatment induces the transcription of ascorbic acid biosynthesis genes leading to the increase in ascorbic acid concentration in plants. Moreover, Pereira da Silva, et al. (2017) reported a marked increase of ascorbic acid concentration in mature-green 'Kumagai' guavas after treated with MeJA. However, certain previous works suggested that hot water immersion did not induce ascorbic acid concentration in a range of fresh commodities such as pomegranate (Mirdehghan et al., 2006), sweet leaf bush (Supapvanich et al., 2012), rambutant (Supapvanich, 2015) and papaya (Supapvanich and Promyou, 2017). From these, we assumed that the increase in ascorbic acid concentration in the treated guava fruits might associate with the action of MeJA rather than $\mathrm{H}$.

\section{Antioxidant enzymes activities, antioxidant capacity and free radical scavenging activity}

The changes of certain antioxidant enzymes activities such as CAT and POD in 'Kim Ju' guava fruits are shown in Fig. 5A and 5B. It was found that $\mathrm{H}+0.1 \mathrm{mM}$ MeJA treatment retained a high level of CAT activity and enhanced POD activity during storage when compared to control fruit. In control fruit, CAT

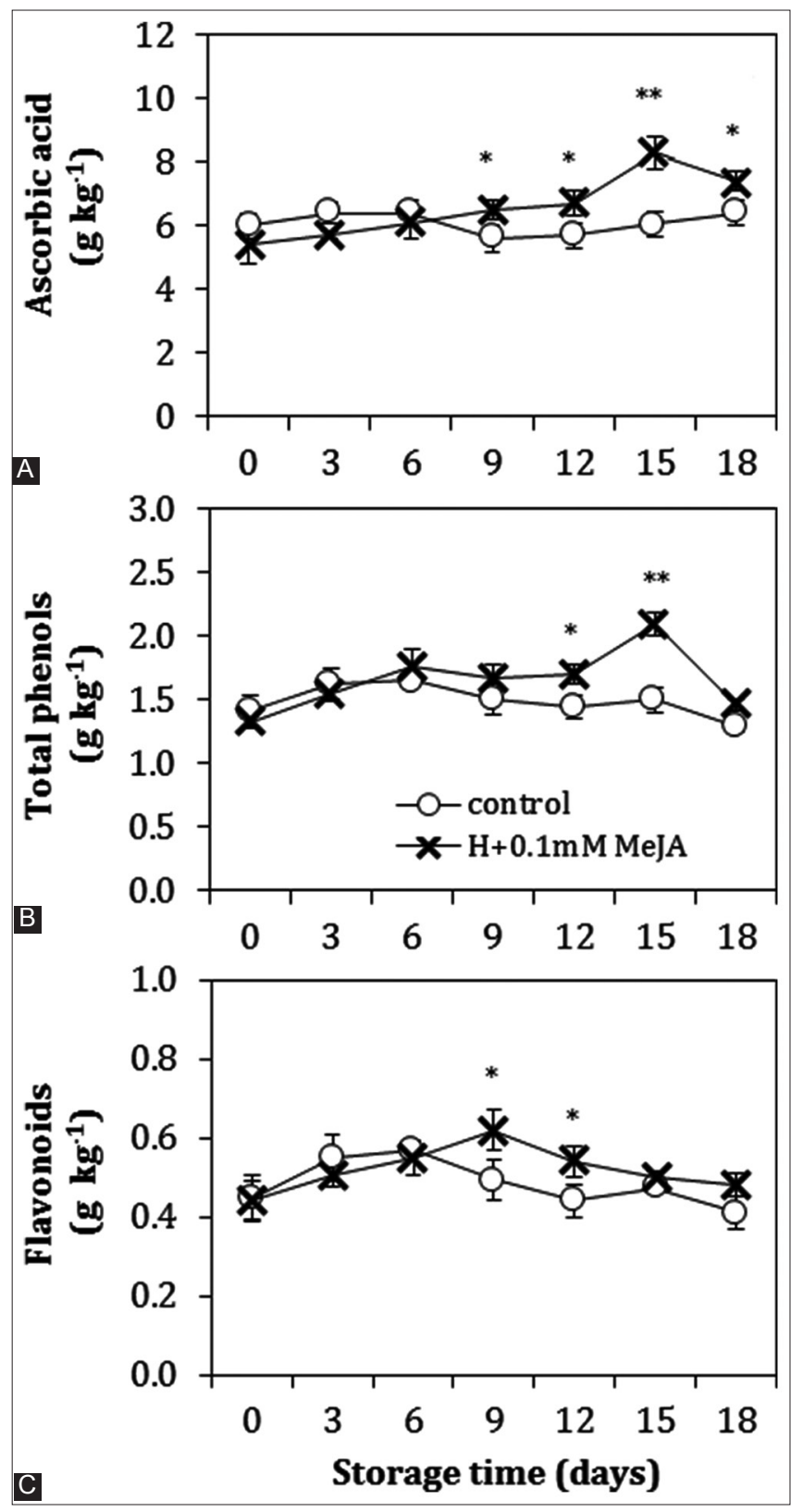

Fig 4. Ascorbic acid (AsA) (A), total phenols (B) and flavonoids (C) contents of 'Kim Ju' guava fruit immersed in water (control) or $\mathrm{H}+0.1$ $\mathrm{mM}$ MeJA during storage at $12 \pm 1^{\circ} \mathrm{C}$ for $18 \mathrm{~d}$. Vertical bars represent the standard deviation (SD) of mean $(n=5)$. Significant differences between untreated (control) and treated 'Kim Ju' guava fruits are indicated with asterisk $\left[{ }^{* *}(p<0.01) ;{ }^{*}(p<0.05)\right]$.

activity apparently decreased during storage for $6 \mathrm{~d}$ and then remained constant over storage whilst POD activity remained constant throughout the storage. In $\mathrm{H}+0.1 \mathrm{mM}$ MeJA treated guavas, CAT activity remained constant during storage for $9 \mathrm{~d}$ and then gradually decreased. Similarly, POD activity also remained constant during the storage for $9 \mathrm{~d}$; afterwards, it obviously increased and reached to a peak on day 12 and then declined. Fig. 5C and 5D show the changes in antioxidant capacity and free radical scavenging activity 


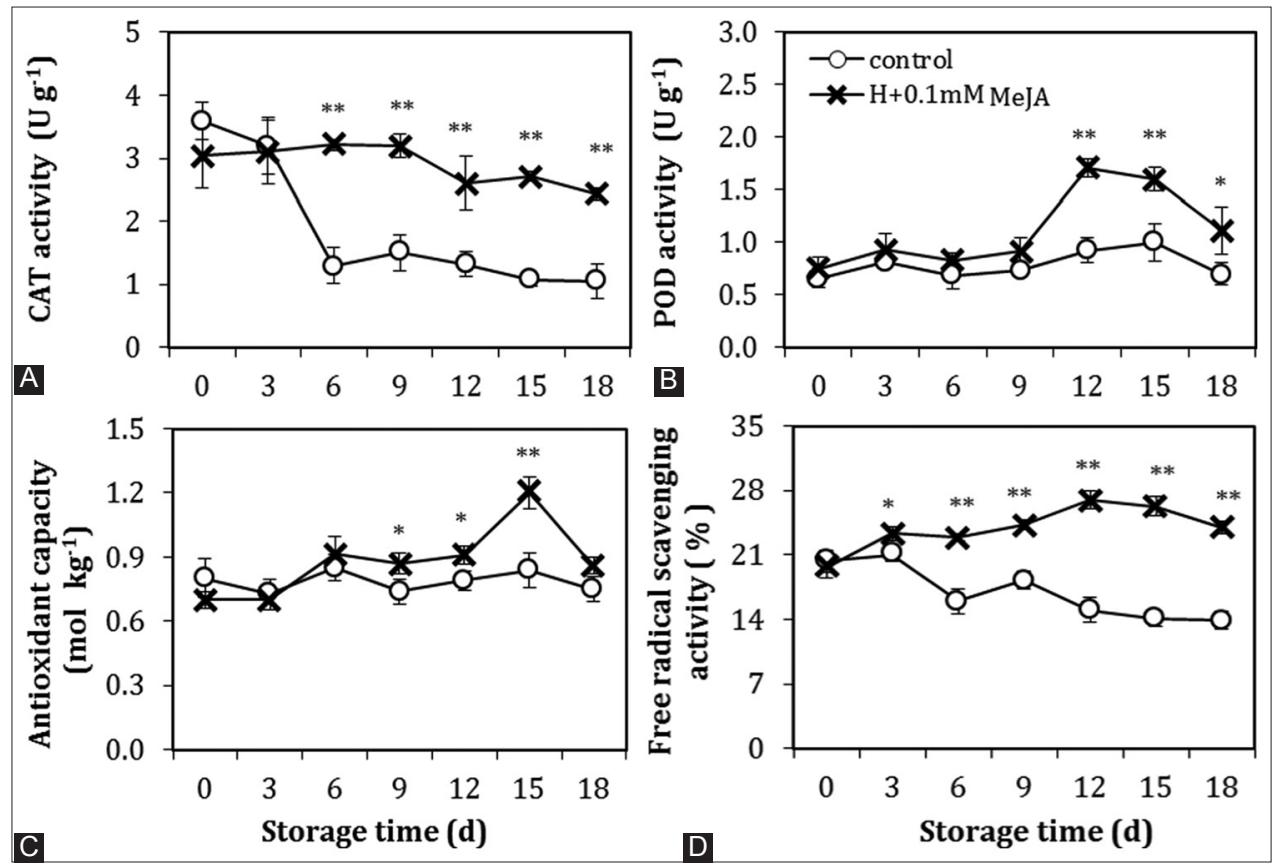

Fig 5. Antioxidant enzyme activities such as CAT (A) and G-POD (B), antioxidant capacity (C) and free radical scavenging activity (D) of 'Kim Ju' guava fruit immersed in water (control) or $\mathrm{H}+0.1 \mathrm{mM}$ MeJA during storage at $12 \pm 1^{\circ} \mathrm{C}$ for $18 \mathrm{~d}$. Vertical bars represent the standard deviation $(\mathrm{SD})$ of mean $(\mathrm{n}=5)$. Significant differences between untreated (control) and treated 'Kim Ju' guava fruits are indicated with asterisk [** $(p<0.01)$; $\left.{ }^{*}(p<0.05)\right]$.

of the both control and $\mathrm{H}+0.1 \mathrm{mM}$ MeJA treated guava fruits during storage. The results revealed that $\mathrm{H}$ + 0.1 mM MeJA treatment enhanced both antioxidant capacity and free radical scavenging activity in guava fruit. In the control, antioxidant capacity remained constant and free radical scavenging activity decreased throughout storage. It has been acknowledged that the levels of antioxidant capacity and free radical scavenging activity in fresh commodities are associated with the concentration of bioactive compounds and the yields of antioxidant enzymes (Cao et al., 2009; Venkatachalam and Meenune, 2015; Asghari and Hasanlooe, 2016; Somata et al., 2017). Regarding to the results shown in Fig. 4, bioactive compounds concentrations of $\mathrm{H}+0.1 \mathrm{mM}$ MeJA treated guava fruit were also concomitant with the higher levels of both antioxidant capacity and free radical scavenging activity when compared to control fruit. In the similar vein, many previous works revealed that both heat and MeJA treatments can encourage the high levels of antioxidant and free radical scavenging activities in plants due to the stimulation of bioactive compounds and antioxidant enzymes activities (Paull and Chen, 2000; Chen et al., 2008; Wang et al., 2008; Meng et al., 2009; Zhang et al., 2009; Bassal and El-Hamahmy, 2011; Supapvanich et al., 2012). Thus, the treatment of $\mathrm{H}+0.1 \mathrm{mM}$ MeJA could improve nutritional value of 'Kim Ju' guava fruit through the stimulation of antioxidant system.

\section{CONCLUSION}

The treatment of $\mathrm{H}+0.1 \mathrm{mM}$ MeJA could preserve visual appearance of 'Kim Ju' guava fruit through the prevention of browning incidence and brown rot during cold storage for $18 \mathrm{~d}$ when compared to $\mathrm{H}$, $0.1 \mathrm{mM}$ MeJA or control treatments. The $\mathrm{H}+0.1 \mathrm{mM}$ MeJA treatment delayed fruit softening due to the maintenance of high level of insoluble pectin and the inhibition of soluble pectin increase during storage. The $\mathrm{H}+0.1 \mathrm{mM}$ MeJA treatment also induced antioxidant capacity and free radical scavenging activity through the enhancement of total phenols, flavonoids and ascorbic acid concentrations, the stimulation of POD activity and the inhibition of CAT activity reduction. In conclusion, $\mathrm{H}+0.1 \mathrm{mM}$ MeJA treatment was a potential means maintaining visual appearance, retarding softening and enhancing nutritional value of ' $\mathrm{Kim}$ Ju' guava fruit during cold storage for $18 \mathrm{~d}$.

\section{ACKNOWLEDGEMENTS}

We thank Department of Agricultural Education, KMITL, for supporting all laboratory facilities and thank P. Boonyaritthongchai, C. Techavuthiporn, R. Tepsorn and P. Youryon for their supervision. This work would not be completed if there was no help of Miss Preyanuch Mitsang and Mr. Boonwat Mahasap. 


\section{Author contributions}

S. Supapvanich designed the work, acquired, analyzed, interpreted the data, and wrote the manuscript. Y. Kernprie operated experiment and collected data. P. Boonyaritthongchai, C. Techavuthiporn, R. Tepsorn and P. Youryon analysed certain biochemical parameters and approved the manuscript.

\section{REFERENCES}

Ahmed, A.R. and J. M. Labavitch. 1978. A simplified method for accurate determination of cell wall uronide content. J. Food Biochem. 1(4): 361-365.

Andrade Cuvi, M. J., A. R. Vincente, A. Concellón and A. R. Chaves. 2011. Changes in red pepper antioxidants as affected by UV-C treatments and storage at chilling temperature. LWT Food Sci. Technol. 44: 1666-1671.

Asghari, M. and A. R. Hasanlooe. 2016. Methyl jasmonate effectively enhanced some defense enzymes activity and total antioxidant content in harvested "Sabrosa" strawberry fruit. Food Sci. Nutr. 4(3): 377-383.

Bassal, M. and M. El-Hamahmy. 2011. Hot water dip and preconditioning treatments to reduce chilling injury and maintain postharvest quality of navel and Valencia oranges during cold quarantine. Postharvest Biol. Technol. 60(3): 186-191.

Benzie, I. F. F. and J. J. Strain. 1996. The ferric reducing ability of plasma (FRAP) as a measure of "antioxidant power": The FRAP assay. Anal. Biochem. 239: 70-76.

Boonyaritthongchai, P., C. Chimvaree, M. Buanong, A. Uthairatanakij and P. Jitareerat. 2017. Effect of methyl jasmonate on physical and chemical properties of mango fruit cv. Nam Dok Mai. Horticulturae. 3(1): 18.

Brand-Williams, W., M. E. Cuvelier and C. Berset. 1995. Use of free radical method to evaluate antioxidant activity. LWT Food Sci. Technol. 28: 25-30.

Cao, S., Y. Zheng, K. Wang, P. Jin and H. Rui. 2009. Methyl jasmonate reduces chilling injury and enhances antioxidant enzyme activity in postharvest loquat fruit. Food Chem. 115: 1458-1463.

Chen, J., L. He, Y. Jiang, Y. Wang, D. C. Joyce, Z. Ji and W. Lu. 2008. Role of phynylalanine ammonia-lyase in heat pretreatmentinduced chilling tolerance in banana fruit. Physiol. Plant. 132(3): 318-328.

El-Buluk, R. E., E. E. Babiker and A. H. Tinay. 1995. Biochemical and physical changes in fruits of four guava cultivars during growth and development. Food Chem. 54(3): 279-282.

FAO. 2011. Food and Agricultural Commodities Production: Guava, Mango, and Mangosteen. Available from: http://www.faostat.fao. org/site/339/default.aspx. [Last accessed on 2017 Aug 01].

González-Aguilar, G. A., M. E. Tiznado-Hernández, R. Zavaleta-Gatica and M. A. Martínez-Téllez. 2004. Methyl jasmonate treatments reduce chilling injury and activate the defense response of guava fruits. Biochem. Biophys. Res. Com. 313: 694-701.

Goulart, N. M. A., Barboza, H. T. G., Saores, A. G., Neves A. C. V. Jr and M. J. de Oliveira Fonseca. 2016. Postharvest physiology and technology for fresh guavas. In: Dimitrov, T. S. and G. C. Stewart., (Eds.), Tropical Fruits. Nova Science Publishers, Inc., New York, pp. 91-108.

Gould, W. P. 1994. Heat quarantine treatments for guavas infested with the Caribbean fruit fly. Proc. Fla. State Hort. Soc. 107: 240-242.

Hashimoto, S. and K. Yamafuji. 2001. The determination of diketoL- gulonic acid, dehydro-L-ascorbic acid, and L-ascorbic acid in the same tissue extract by 2, 4-dinitrophenol hydrazine method. J. Bio. Chem. 147: 201-208.

Heredia, J. B. and L. Cisneros-Zevallos. 2009. The effect of exogenous ethylene and methyl jasmonate on pal activity, phenolic profiles and antioxidant capacity of carrots (Daucus carota) under different wounding intensities. Postharvest Biol. Technol. 51(2): 242-249.

Jin, P., Y. Zheng, S. Tang, H. Rui and C. Y. Wang. 2009. A combination of hot air and methyl jamonate vapour treatment alleviates chilling injury of peach fruit. Postharvest Biol. Technol. 52: 24-29.

Jin, P., Y. Duan, L. Wang, J. Wang and Y. Zheng. 2014. Reducing chilling injury of loquat fruit by combined treatment with hot air and methyl jasmonate. Food Bioprocess Technol. 7(8): 2259-2266.

Kader, A. A. 1999. Guava: Recommendations for Maintaining Postharvest Quality. Division of Agriculture and Natural Resources, University of California. Available from: http:// postharvest.ucdavis.edu/PFfruits/guava. [Last accessed on 2019 Apr 04].

Khan, A. S. and Z. Singh. 2007. Methyl jasmonate promotes fruit ripening and improves fruit quality in Japanese plum. J. Hortic. Sci. Biotech. 82(5): 695-706.

Kim H. J., F. Chen, X. Wang and J. H. Choi. 2006. Effect of methyl jasmonate on phenolics, isothiocyanate, and metabolic enzymes in radish sprout (Raphanus sativus L.). J. Agric. Food Chem. 54(19): 7263-7269.

Klein, J. D., S. Lurie and R. Ben-Arie. 1990. Quality and cell wall components of "Anna" and "Granny Smith" apples treated with heat, calcium and ethylene. J. Am. Soc. Hortic. Sci. 115: 954-958.

Lara, I., P. García and M. Vendrell. 2006. Post-harvest heat treatments modify cell wall composition of strawberry (Fragaria $x$ ananassa Duch.) fruit. Sci. Hortic. 109: 48-53.

Lurie, S., S. Othman and A. Borochov. 1995. Effects of heat treatment on plasma membrane of apple fruit. Postharvest Biol. Technol. 5: 29-38.

McGuire, R. 1997. Market quality of guavas after hot-water quarantine treatment and application of carnuba wax coating. HortSci. 32(2): 271-274

Meng, X., J. Han, Q. Wang and S. Tian. 2009. Changes in physiology and quality of peach fruits treated by methyl jasmonate under low temperature stress. Food Chem. 114: 1028-1035.

Mirdehghan, S. H., M. Rahemi, M. Serrano, F. Guillén, D. MartínezRomero and D. Valero. 2006. Prestorage heat treatment to maintain nutritive and functional properties during postharvest cold storage of pomegranate. J. Agric. Food Chem. 54(22): 8495-8500

Murray, R., C. Lucangeli, G. Polenta and C. Budde. 2007. Combined pre-storage heat treatment and controlled atmosphere storage reduced internal breakdown of "flavorcrest" peach. Postharvest Biol. Technol. 44: 116-121.

Paull, R. E. and N. J. Chen. 2000. Heat treatment and fruit ripening. Postharvest Biol. Technol. 21: 21-37.

Pereira da Silva, B. M., R. M. Binoti, P. Cia, S. R. T. Valentini and I. U. Bron, I. U. 2017. Ripening of "Kumagai" guavas and antracnose control as affected by methyl jasmonate. Bragantia. 76(1): 167-176.

Promyou, S., S. Supapvanich, B. Boodkord and M. Thangapiradeekajorn. 2012. Alleviation of chilling injury in jujube fruit (Ziziphus jujube Mill) by dipping in $35^{\circ} \mathrm{C}$ water. Kasetsart J. Nat. Sci. 46: 107-119.

Rai, M. K., P. Asthana, V. S. Jaiswal and U. Jaiswal. 2010. Biotechnologies advances in guava (Psidium guajava L.): Recent developments and prospects for further research. Trees. 24: 1-12. 
Rui, H., S. Cao, H. Shang, P. Jin, K. Wang and Y. Zheng. 2010. Effects of heat treatment on internal browning and membrane fatty acid in loquat fruit in response to chilling stress. J. Sci. Food Agric. 90(9): 1557-1561.

Schirra, M., A. Palma, S. D’Aquino, A. Angioni, E. V. Minello, M. Melis and P. Cabras. 2007. Influence of postharvest hot water treatment on nutritional and functional properties of kumquat (Fortunella japonica Lour. Swingle cv. Ovale) fruit. J. Agric. Food Chem. 56(2): 455-460.

Silip, J. J. and S. A. Hajar. 2007. Relationship between precooling storage temperature and storage duration to the quality characteristics of guava (Psidium Guajava L. cv. Kampuchea). Acta Hortic. 735: 535-546.

Slinkard, K. and V. L. Singleton. 1977. Total phenol analysis: Automation and comparison with manual methods. Am. J. Enol. Vitic. 28: 49-55.

Somata, M. K., L. Bhatt, N. Garg and N. Geat. 2017. Defense induce by jasmonic acid: A review. Inter. J. Curr. Microbiol. Appl. Sci. 6(5): $2467-2474$.

Supapvanich, S. 2015. Effects of salicylic acid incorporated with lukewarm water dips on the quality and bioactive compounds of rambutan fruit (Nephelium lappaceum L.). CMU J. Nat. Sci. 14(1): 23-27.

Supapvanich, S. and S. Promyou. 2017. Hot water incorporated with salicylic acid dips maintaining physicochemical quality of 'Holland' papaya fruit stored at room temperature. Emir. J. Food Agric. 29(1): 18-24.

Supapvanich, S., R. Arkajak and K. Yalai. 2012. Maintenance of postharvest quality and bioactive compounds of fresh-cut leaf bush (Saurapus androgynous L. Merr.) through hot $\mathrm{CaCl}_{2}$ dips Int. J. Food Sci. Technol. 47: 2662-2670.

Venkatachalam, K. and M. Meenune. 2015. Effect of methyl jasmonate on physiological and biochemical quality changes of longkong fruit under low temperature storage. Fruits. 70: 69-75.

Wang, M. H. and H. L. Lin. 2009. Effect of cold storage and vapour heat treatment on the quality of 'Di-Wang' guava (Psidium guajava L.) fruits. J. Taiwan Soc. Hort. Sci. 55(2): 113-126.

Wang, S. Y. and W. Zheng. 2005. Preharvest application of methyl jasmonate increases fruit quality and antioxidant capacity in raspberries. Int. J. Food Sci. Technol. 40(2): 187-195.

Wang, H., Z. Zhang, X. Huang, Y. Jiang and X. Pang. 2008. Hot water dipping induced chilling resistance of harvested banana fruit. Acta Hortic. 804: 513-522.

Wang, J., J. Qian, L. Yao and Y. Lu. 2015. Enhanced production of flavonoids by methyl jasmonate elicitation in cell suspension culture of Hypericum perforatum. Bioresour. Bioprocess. 2: 5.

Wills, R. B. H., W. B. McGlasson, D. Graham and D. C. Joyce. 2007. Postharvest, An Introduction to Physiology and Handling of Fruit, Vegetables and Ornamentals. 5th ed. University of New South Wales Press, Sydney.

Wolucka, B. A., A. Goossens and D. Inzé. 2005. Methyl jasmonate stimulates the de novo biosynthesis of Vitamin $\mathrm{C}$ in plant cell suspensions. J. Exp. Bot. 56: 2527-2538.

Zhao, M. L., J. N. Wang, W. Shan, J. G. Fan, J. F. Kuang, K. Q. Wu, X. P. Li, W. X. Chen, F. Y. He, J. Y. Chen and W. J. Lu. 2013. Induction of jasmonate signalling regulators MaMYC2s and their physical interactions with MaICE1 in methyl jasmonate-induced chilling tolerance in banana fruit. Plant Cell Environ. 36(1): 30-51. 